\title{
РЕЦЕНЗІЯ \\ на монографію Корнієнка Максима Вікторовича «Концептуальні основи протидії насильницьким злочинам щодо дітей»1
}

Легка О. В.

Починаючи з другої половини XX століття проблематика прав людини, їх забезпечення та захисту виходить за межі національної держави та набуває універсального характеру. Передусім правники пов'язують цей процес з прийняттям у 1948 році Загальної декларації прав людини i, зважаючи на іiі належність до soft law, прийняття у 1966 році двох Пактів: про громадянські та політичні права і про економічні, соціальні та культурні права. Однак, як справедливо зазначається прибічниками теорії гендерної рівності, права людини інтерпретуються зазвичай як можливості «білого, дорослого, чоловіка». Розуміння цього у межах західної правової культури призвело до прийняття резолюцією 1386 (XIV) Генеральної Асамблеї Організації Об'єднаних Націй Декларації прав дитини (1959 рік). Доречно зауважити, що іманентність цьому міжнародному документу характерy soft law стала фактором необхідності прийняття міжнародного договору, норми якого $\epsilon$ jus cogens - Конвенції про права дитини, що сталося аж через тридцять років, у 1989 році (ця Конвенція була ратифікована постановою Верховної Ради РСР № 789-XII від 27 лютого 1991 року). Таким чином, міжнародне співтовариство визнало необхідність урахування уразливого стану дитини під час вирішення питання забезпечення ії прав.

Водночас не можемо не акцентувати увагу на тому, що наприкінці XX - початку XXI ст. відбуваються значні соціальні зміни, інтенсивно розвивається сфера інтелектуальних технологій, мережа Internet дійсно стає «всесвітнім павутинням», мобільний зв'язок $\epsilon$ загальнодоступним, що не могло не позначитися на дітях. Так, на це вказують результати соціологічного дослідження серед дітей, проведеного в Україні у межах міжнародного проекту “Health behaviour school-aged children” (Здоров'я та поведінкові орієнтації учнівської молоді) за підтримки Представництва Дитячого фонду ООН (ЮНІСЕФ). Наголосимо, що у монографії М.В. Корнієнка використано результати цього дослідження, що посилило емпіричну основу та об'єктивність наведених положень та зроблених автором висновків.

При цьому в окреслений час відбувається і зростання рівня злочинності загалом, і збільшення кількості злочинів, що вчиняються відносно дітей (у тому числі і насильницьких злочинів), що $є$ фактором необхідності вжиття органами публічної влади заходів ефективної протидії означеним негативним соціальним явищам, адже у будь-якому суспільстві перманентно має проводитись комплекс заходів з запобігання та припинення злочинів щодо дітей, а особливо це стосується держав, у яких спостерігається тенденція до зростання кількості таких правопорушень.

Таким чином, тематика протидії насильницьким злочинам щодо дітей, будучи актуальною у всіх цивілізованих державах, для вітчизняної правничої науки набуває особливої ваги. Тому поява монографії М.В. Корнієнка $\epsilon$ на часі. Проблематика, обрана автором, потребувала нагального розв'язання з використанням системного підходу та урахуванням сучасних реалій протидії злочинності.

Варто відзначити саме комплексність проведеного М.В. Корнієнком дослідження. Так, у монографії відображено як загальнотеоретичний аспект, так і адміністративно-правовий, кримінально-правовий, кримінологічний, кримінально-процесуальний, криміналістичний аспекти протидії злочинам, що вчиняються відносно дітей, а також висвітлено окремі можливості використання засобів та заходів, передбачених Законом України «Про оперативно-розшукову діяльність». Саме це і дозволило автору визначити концептуальні основи протидії насильницьким злочинам щодо дітей та провести дескрипцію цих основ.

У першому розділі дослідження М.В. Корнієнком висвітлено загальні положення протидії насильницьким злочинам щодо дітей. Автором не лише з'ясовано стан нормативно-правового регулювання протидії насильству стосовно дітей та наукової розробки предмету пізнання, а і визначено поняття та сутність насильства стосовно дітей. М.В. Корнієнко долучився до наукової дискусії відносно розуміння насилля в праві у контексті визначеного автором предмету дослідження, відзначаючи, що «інтерпретація терміну «насилля» кримінально-правовою і кримінологічною науками відрізняється від загальноприйнятого у сучасних умовах розуміння цього поняття, обмежуючи його зміст лише застосуванням фізичної сили та погрози його застосування». Системною і доволі ґрунтовною $\epsilon$ дескрипція автором правової основи протидії кримінально-правовими засобами злочинам щодо дітей. Автором проаналізовано норми як внутрішньодержавного законодавства, так і міжнародних договорів, які прямо чи опосередковано застосовуються у діяльності органів публічної влади

${ }^{1}$ Корнієнко М.В. Концептуальні основи протидії насильницьким злочинам щодо дітей : монографія. Одеса : ОдУВС, 2019.318 с.

Легка О. В., 2019 
3 виконання завдання припинення i запобігання злочинам щодо дітей. При цьому М.В. Корнієнко використав різні критерії класифікації аналізованих правових приписів, що дозволило достатньою мірою висвітлити нормативно-правове регулювання протидії насильству стосовно дітей, описавши у тому числі і норми soft law, i hard law. Автором проаналізовано відповідні норми Конвенції про права дитини (1989р.), Мінімальних стандартних правил Організації Об'єднаних Націй, що стосуються відправлення правосуддя щодо неповнолітніх («Пекінські правила») (1985 р.), Усесвітньої декларації про забезпечення виживання, захисту і розвитку дітей (1990р.), Конвенції Ради Європи про запобігання насильству стосовно жінок і домашньому насильству та боротьбу із цими явищами (2011р.), Конвенції Ради Європи про захист дітей від сексуальної експлуатації та сексуального насильства (2007р.). Цілком правильною $\epsilon$ інтенція М.В. Корнієнка на Конвенції про захист прав людини та основоположних свобод та практиці Європейського суду з прав людини, яка розкриває імпліцитний характер норм цієї Конвенції.

У розділі 2 монографії автором проведена криміналістична характеристика насильницьких злочинів щодо дітей, при цьому залучено значний обсяг статистики, графіків, рішень національних судових органів тощо. Виходячи з дескрипції автора, заслуговує на увагу у контексті засобів як припинення і притягнення винної особи до відповідальності, так і запобігання насильницьких злочинів щодо дитини, необхідність володіння знаннями про особливості віктимології таких злочинів працівниками правоохоронних органів та соціальних служб, які залучаються до досудового розслідування цих правопорушень та допомоги дитині.

Важливою частиною проведеного М.В. Корнієнком дослідження $\epsilon$ висвітлення проблематики організації виявлення, розслідування та попередження насильницьких злочинів щодо дітей (розділ 3) і тактики проведення окремих слідчих (розшукових) дій під час розслідування насильницьких злочинів щодо дітей (розділ
4). Доволі обґрунтованим є висновок автора про те, що, виходячи з психосоматичних особливостей потерпілого, наявності знань, умінь і навичок поводження з дітьми, які стали учасниками кримінально-правових відносин, доцільно повноваження з організації виявлення насильницьких злочинів щодо дітей покласти саме на ці підрозділи. При цьому, на думку М.В. Корнієнка, ці підрозділи мають стати окремим структурним складником Національної поліції, що потребує внесення змін Закону України «Про Національну поліцію».

В умовах глобалізації та інтеграції особливого значення набувають компаративні дослідження. Тому цілком закономірним $\epsilon$ зміст п'ятого розділу монографії М.В. Корнієнка, у якому висвітлюється взаємодія та міжнародне співробітництво під час розслідування насильницьких злочинів щодо дітей. Важливою є дескрипція автором таких форм міжнародного співробітництва в боротьбі з насильницькими злочинами щодо дітей як координація дій по боротьбі зі злочинністю (обмін інформацією); підписання договорів про боротьбу з міжнародними злочинами і злочинами міжнародного характеру; правова допомога по кримінальних справах; проведення оперативно-розшукових заходів; проведення слідчих дій; профілактика злочинів; спільні заходи щодо припинення злочинних дій і притягнення винних до відповідальності.

Таким чином, у монографії Корнієнка Максима Вікторовича «Концептуальні основи протидії насильницьким злочинам щодо дітей» комплексно розв'язується важлива наукова правова проблема. Рецензована наукова робота $\epsilon$ вагомим внеском у розвиток вітчизняної правничої науки і може бути основою для подальших наукових розробок окремих аспектів висвітленої проблематики.

Легка О. В.

доктор юридичних наук, доцент, завідувач кафедри кримінально-правових дисциплін Дніпровського гуманітарного університету 